\title{
Pengaruh Pengembangan Karir dan Motivasi Terhadap Kepuasan Kerja Pegawai Pada Kantor Badan Pendapatan Daerah Provinsi Sumatera Selatan
}

\author{
Ratna Puji Lestari ${ }^{1}$, Suhada ${ }^{2}$ \\ ${ }^{1}$ Alaumni Manajemen, FE Universitas PGRI Palembang \\ 2Dosen Manajemen, FE Universitas PGRI Palembang, suhada@univpgri-palembang.ac.id
}

\begin{abstract}
ABSTRAK
Metode yang digunakan metode kuantitatif. Dengan populasi seluruh pegawai berjumlah 101 orang pegawai. Sampel dalam penelitian ini diambil menggunakan rumus Slovin dan didapat 51 orang pegawai pada bagian umum, pengawasan dan keuangan pada Kantor Badan Pendapatan Daerah Provinsi Sumatera Selatan. Teknik pengumpulan data yang dilakukan dengan menggunakan kuesioner dan dokumentasi. Analisis data pada penelitian ini menggunakan bantuan SPSS Versi 22. Berdasarkan hasil perhitungan yang diperoleh 1) Signifikan variabel Pengembangan Karir terhadap Kepuasan kerja sebesar 0,038 $<0,05(5 \%)$. Dengan demikian dapat disimpulkan terdapat pengaruh pengembangan karir terhadap kepuasan kerja pegawai. 2) dapat diketahui hasil Signifikan Motivasi terhadap Kepuasan Kerja sebesar 0,012 < 0,05 (5\%). Dengan demikian dapat disimpulkan bahwa terdapat pengaruh motivasi terhadap kepuasan kerja pegawai. 3) Dapat diketahui hasil Signifikan Pengembangan Karir dan Motivasi terhadap Kepuasan Kerja Pegawai sebesar 0,000 $<0,05(5 \%)$. Dengan demikian dapat disimpulkan bahwa terdapat pengaruh Pengembangan Karir dan Motivasi secara bersama-sama terhadap Kepuasan Kerja Pegawai pada Kantor Badan Pendapatan Daerah Provinsi Sumatera Selatan.
\end{abstract}

Kata kunci: Pengembangan Karir, Motivasi, dan Kepuasan Kerja Pegawai

\section{A. PENDAHULUAN}

Dalam suatu organisasi/instansi pemerintahan segala sesuatu yang dilakukan dituntut untuk dapat berjalan lancar, cepat dan terarah dalam rangka untuk mencapai tujuan secara efektif dan efisien. Untuk mencapai setiap tujuan yang telah ditetapkan oleh suatu organisasi/instansi tersebut, dibutuhkan peranan sumber daya manusia yang berperan penting dalam mencapai tujuan organisasi atau instansi dengan baik dan profesional. $\mathrm{Hal}$ ini dikarenakan pegawai merupakan penentu serta pelaku dalam keberhasilan suatu instansi pemerintahan dalam memberikan pelayanan kepada masyarakat serta mencapai tujuan yang telah ditetapkan.

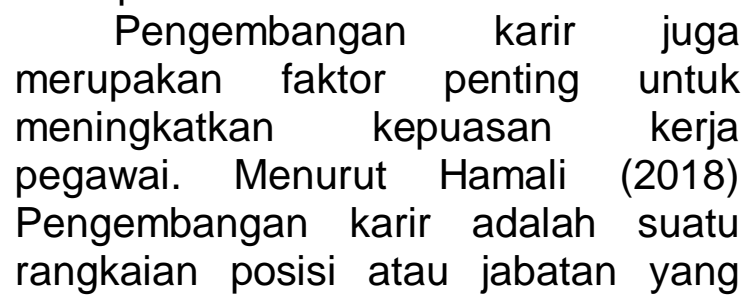

ditempati seseorang selama masa kehidupan tertentu. Menurut Lisdiani (2017) dengan adanya pengembangan karir yang baik maka pegawai akan merasa termotivasi untuk lebih berprestasi sehingga menciptakan rasa puas dalam melaksanakan pekerjaannya dan memberikan kontribusi yang maksimal terhadap instansi. Pengembangan karir dilakukan dengan promosi jabatan dan pelatihan kerja agar pegawai semakin baik dalam bekerja dan puas atas hasil yang ia kerjakan.

Menurut Noor (2013) motivasi adalah suatu dorongan di dalam diri untuk melakukan aktivitas pekerjaan untuk mencapai tujuannya. Pegawai yang memiliki motivasi kerja tinggi tentunya akan lebih bersemangat dalam bekerja sehingga mampu menyelesaikan pekerjaan yang dibebankan oleh instansi tepat waktu serta dapat meningkatkan tingkat kepuasan itu sendiri. 
Masalah motivasi r pada
organisasi atau instansi haruslah
dijadikan sebagai perhatian yang serius dalam manajemen sumber daya manusia. Karena pada organisasi atau instansi modern saat ini harus menjadikan pegawai sebagai aset, bukan hanya sebagai alat produksi semata. Untuk itu organisasi atau instansi perlu menciptakan suatu kondisi kondusif yang dapat membuat pegawai merasa nyaman, terpenuhi kebutuhannya, sehingga diharapkan motivasi mereka juga tetap terjaga untuk bersama-sama mencapai tujuan serta visi dan misi di Instansi.

Selain pengembangan karir dan motivasi, suatu organisasi atau instansi harus memperhatikan kepuasan kerja pegawai, bagaimana menjaga dan mengelolannya karena pegawai yang dalam bekerja mereka tidak merasakan kenyamanan, kurang dihargai, tidak bisa mengembangkan segala potensi yang dimiliki maka secara otomatis pegawai tidak fokus dan kurang berkonsentrasi secara penuh terhadap pekerjaannya. Menurut Sutrisno (2015) Kepuasan kerja pada dasarnya merupakan suatu sikap pegawai terhadap pekerjaan yang berhubungan dengan situasi kerja, kerjasama antar pegawai, imbalan yang diterima dalam kerja, dan hal-hal yang menyangkut fisik dan psikologis. Wijayanti dkk, (2017) pada hakikatnya, setiap pegawai mempunyai tingkat kepuasan kerja yang berbeda sehingga tingkat kepuasan kerja antara satu pegawai dengan pegawai lainnya sangat relatif.

Oleh karena itu, penulis menduga bahwa pengembangan karir dan motivasi kerja memiliki kontribusi terhadap kepuasan kerja pegawai. Untuk mencari kebenarannya maka permasalahan tersebut perlu diteliti.

Berdasarkan pengamatan di Kantor Badan Pendapatan Daerah
Provinsi Sumatera Selatan tersebut, permasalahan yang dihadapi di adalah lemahnya supervisi yang dilakukan seorang atasan terhadap bawahan sehingga mengakibatkan pekerjaan yang dilakukan kurang maksimal dan ada sebagian pegawai yang keluar disaat jam kerja. Hal ini yang perlu mendapatkan perhatian dari pihak manajerial terutama pemimpin, agar dapat sedini mungkin mencegah dan berupaya meningkatkan kualitas sumber daya manusiannya.

\section{A. KAJIAN TEORI}

\section{Pengembangan Karir}

Samsudin (2010) Pengembangan karir (career development) adalah suatu kondisi yang menunjukkan adanya peningkatan status seorang dalam suatu organisasi pada jalur karier yang telah ditetapkan dalam organisasi yang bersangkutan.

Hamali (2018) Pengembangan karir adalah suatu rangkaian posisi atau jabatan yang ditempati seseorang selama masa kehidupan tertentu.

Menurut Sinambela (2016) Pengembangan karir adalah upaya yang dilakukan oleh organisasi dalam merencanakan karier pegawaiannya, yang disebut sebagai manajemen karir, antara lain merencanakan, melaksanakan, dan mengawasi karier.

Berdasarkan pendapat para ahli di atas, dapat disimpulkan bahwa pengembangan karir adalah suatu kondisi yang menunjukkan adanya peningkatan status atau jabatan yang ditempati seseorang dalam organisasi untuk mencapai karier yang diinginkan.

\section{Motivasi}

Menurut Noor (2013) Motivasi adalah dorongan dalam dan luar diri untuk melakukan aktivitas pekerjaan untuk mencapai tujuannya. Menurut Hasibuan dalam Sutrisno (2015) Motivasi adalah pemberian daya 
penggerak yang menciptakan kegairahan kerja seseorang agar mereka mau bekerja sama, bekerja efektif, dan terintegrasi dengan segala daya upayanya untuk mencapai kepuasan.

Menurut Fahmi (2017) Motivasi adalah aktivitas perilaku yang bekerja dalam usaha memenuhi kebutuhankebutuhan yang diinginkan. Samsudin (2010:281) Motivasi adalah proses memengaruhi atau mendorong dari luar terhadap seseorang atau kelompok kerja agar mereka mau melaksanakan sesuatu yang telah diharapkan.

Dari beberapa pendapat di atas dapat disimpulkan bahwa motivasi merupakan suatu dorongan dari dalam dan luar diri untuk melakukan aktivitas pekerjaan dan menciptakan kegairahan kerja seseorang agar mereka mau bekerja sama dalam usaha memenuhi kebutuhankebutuhan yang diinginkan.

\section{Kepuasan Kerja}

Menurut Sutrisno (2015)

Kepuasan kerja adalah suatu sikap karyawan terhadap pekerjaan yang berhubungan dengan situasi kerja, kerjasama antar karyawan, imbalan yang diterima dalam kerja, dan hal-hal yang menyangkut fisik dan psikologis.

Hamali (2018) Kepuasan kerja adalah setiap orang yang bekerja mengharapkan dapat memperoleh kepuasan dari tempatnya bekerja.

Menurut Robbins dalam Wibowo (2014) Kepuasan kerja adalah sikap umum terhadap pekerjaan seseorang yang menunjukkan perbedaan antara jumlah penghargaan yang diterima pekerja dan jumlah yang mereka yakini seharusnya mereka terima.

Menurut Rivai, dkk (2014) Kepuasan kerja adalah setiap individu yang memiliki tingkat kepuasan yang berbeda-beda sesuai dengan sistem nilai yang berlaku pada dirinya.

Dari pendapat di atas dapat disimpulkan bahwa kepuasan kerja adalah suatu sikap karyawan yang bekerjasama untuk memperoleh kepuasan yang berbeda-beda sesuai dengan sistem nilai yang berlaku pada dirinya.

\section{METODE PENELITIAN}

Penulis menggunakan metode kuantitatif. Menurut Sugiyono (2016) Metode kuantitatif dapat diartikan sebagai metode penelitian yang berdasarkan pada filsafat positivisme, digunakan untuk meneliti pada populasi atau sampel tertentu, pengumpulan data menggunakan instrument penelitian, analisis data bersifat kuantitatif/statistik, dengan tujuan untuk menguji hipotesis yang telah ditetapkan.

\section{POPULASI DAN SAMPEL}

1) Populasi

$$
\text { Menurut Sugiyono }
$$
populasi adalah wilayah generalisasi yang terdiri atas obyek/subyek yang mempunyai kualitas dan karakteristik tertentu yang ditetapkan oleh peneliti untuk dipelajari dan kemudian ditarik kesimpulannya. Populasi dalam penelitian ini adalah seluruh pegawai yang ada di Kantor Badan Pendapatan Daerah Provinsi Sumatera Selatan yang berjumlah 101 karyawan.

\section{2) Sampel}

Menurut Sugiyono (2016) Sampel adalah bagian dari jumlah karakteristik yang dimiliki oleh populasi tersebut.

Pada penelitian ini, pengambilan jumlah responden menggunakan rumus Slovin (Sujarweni 2015) sampel yang akan ditentukan oleh peneliti dengan persentase kelonggaran ketidaktelitian adalah sebesar $10 \%$. 


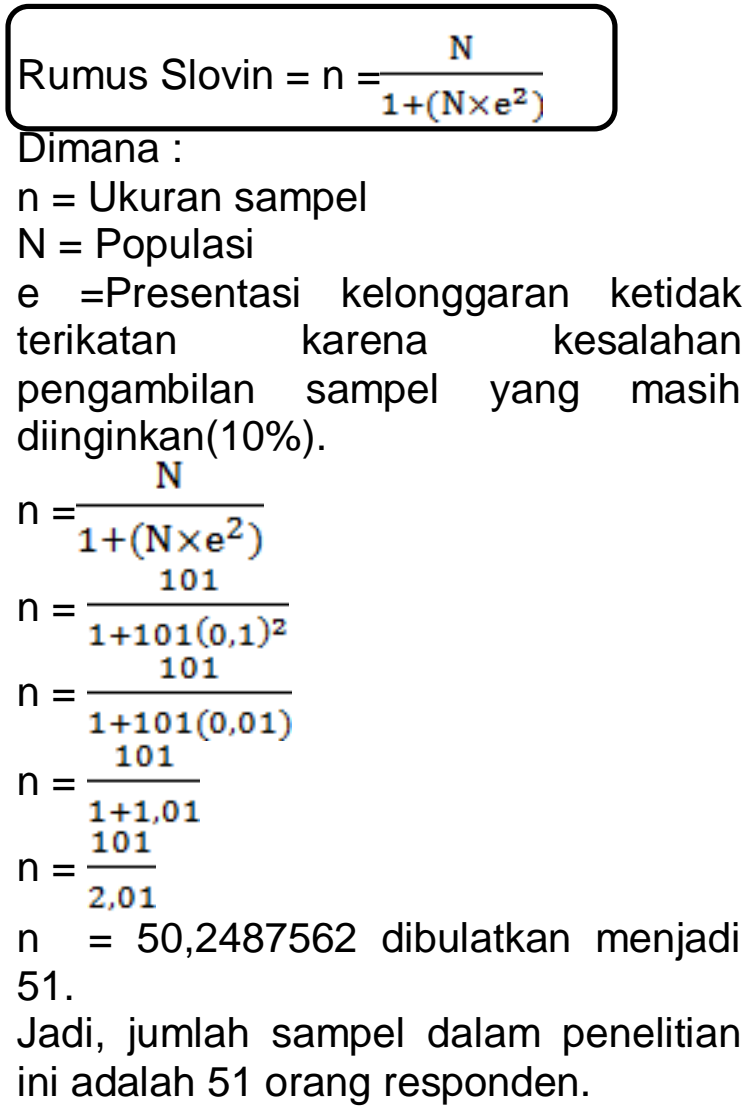

D. TEKNIK PENGUMPULAN DATA

Teknik pengumpulan data penulis menggunakan teknik kuesioner (angket) dan Observasi.

1. Angket atau kuesioner

Sugiyono (2018) kuesioner adalah teknik pengumpulan data yang dilakukan dengan cara memberi seperangkat pertanyaan atau pernyataan tertulis kepada responden untuk dijawab.

2. Dokumentasi

Dokumentasi merupakan mencari data mengenai catatan peristiwa yang sudah berlalu, bentuk dokumentasi berupa catatan, buku-buku, majalah, dokumen peraturan-peraturan, notulen rapat, catatan harian maupun dokumentasi kegiatan selama penelitian berlangsung seperti foto-foto hasil kegiatan dan dokumentasi lainnya yang dianggap penting.

\section{E. TEKNIK ANALISIS DATA}

\section{Analisis Regresi Linier Berganda}

Sugiyono (2013) analisis regresi linier berganda untuk memprediksi seberapa jauh perubahan variabel dependen, bila nilai variabel independen dirubah-rubah atau ditarikturunkan. Dengan ini peneliti menggunakan regresi berganda dengan tiga variabel yaitu memprediksi hubungan antara dua variabel bebas dengan satu variabel terikat. Persamaan regresi dalam penelitian ini adalah untuk mengetahui, seberapa besar pengaruh pengembangan karir dan motivasi terhadap kepuasan kerja pegawai.

Persamaan regresi berganda dirumuskan :

$\dot{Y}=a+b_{1} X_{1}+b_{2} X_{2}$

Keterangan :

Ý: Variabel Terikat Kepuasan Kerja

a : Bilangan konstanta

$b_{1}$ : Koefisien Pengembangan Karir

$\mathrm{b}_{2}$ : Koefisien Motivasi

$\mathrm{X}_{1}$ : Variabel Bebas Pengembangan Karir

$\mathrm{X}_{2}$ : Variabel Bebas Motivasi.

\section{Koefisien Korelasi}

Sugiyono (2013:) analisis koefisie korelasi digunakan untuk membandingkan hasil pengukuran dua variabel yang berbeda agar dapat menentukan hasil hubungan antara variabel.

Tabel 2

Interpretasi Koefisien Korelasi

\begin{tabular}{|c|c|}
\hline Interval Koefisien & Tingkat Hubungan \\
\hline $0,00-0,199$ & Sangat rendah \\
\hline $0,20-0,399$ & Rendah \\
\hline $0,40-0,599$ & Sedang \\
\hline $0,60-0,799$ & Kuat \\
\hline $0,80-1,00$ & Sangat kuat \\
\hline
\end{tabular}


Koefisien Determinasi $\left(\mathbf{R}^{2}\right)$

Siregar (2013) Koefisien determinasi $\left(R^{2}\right)$ adalah angka yang menyatakan atau digunakan untuk mengetahui konstribusi atau sumbangan yang diberikan oleh sebuah variabel atau lebih $X$ (bebas) terhadap variabel $Y$ (terikat). Adapun teknik analisisis yang digunakan dalam pengujian koefisien determinasi dengan alat bantu dengan menggunakan SPSS for windows versi

\section{Kriteria Pengujian Hipotesis Uji t (secara parsial)}

Priyatno (2014) uji t digunakan untuk mengetahui apakah variabel independen secara parsial berpengaruh terhadap variabel dependen.

Untuk menguji apakah hipotesis yang dianjurkan diterima atau ditolak dapat digunakan uji t (uji satu sisi).

1. Jika $t$ hitung $\leq t$ tabel maka Ho diterima dan Ha ditolak

2. Jika $t$ hitung $>t$ tabel maka Ho ditolak dan Ha diterima

Dalam uji $t$ ini dilakukan pada derajat kebebasan (n-k-1), dimana $n$ adalah jumlah responden dan $\mathrm{k}$ adalah jumlah variabel. Untuk tingkat keyakinan yang digunakan adalah $95 \%$ atau $\alpha=5 \%$.

\section{Uji F (secara simultan)}

Sujarweni (2015) Uji $f$ adalah penguji signifikan persamaan yang digunakan untuk mengetahui seberapa besar pengaruh bebas $\left(X_{1}, X_{2}\right)$ secara bersama-sama terhadap variabel terikat $(\mathrm{Y})$.

Langkah-langkah :

1. Menentukan $\mathrm{Ho}$ dan $\mathrm{Ha}$

2. Tingkat signifikan

Tingkat signifikan yang digunakan adalah $0,05(\mathrm{a}=5 \%)$

3. Menentukan $f_{\text {hitung }}$ berdasarkan output data dan menentukan $f_{\text {tabel }}$

4. Kriteria pengujian

Ho diterima jika $f_{\text {hitung }<} f_{\text {tabel }}$ atau Ho ditolak jika $f_{\text {hitung }}>f_{\text {tabel }}$ $\mathrm{Ha}$ diterima jika $f_{\text {hitung } \geq} f_{\text {tabel }}$ atau Ha ditolak jika $f_{\text {hitung }} f_{\text {tabel }}$

5. Membandingkan $f_{\text {hitung }}$ dan $f_{\text {tabel }}$

Dalam penelitian ini digunakan analisis regresi berganda yang diolah dengan perangkat lunak SPSS for windows versi 22.

\section{F. HASIL PENELITIAN DAN PEMBAHASAN \\ 1) Hasil Penelitian}

\section{Regresi Linier Berganda}

Analisisregresi linear sederhana adalah untuk melihat pengaruh linear antara dua variabel bebas $X$ atau lebih terhadap variabel terikat $Y$. Selain itu untuk memprediksi nilai variabel terikat apabila variabel bebas diketahui (nilai variabel bebas mengalami kenaikan atau penurunan).

Hasil analisis regresi dengan menggunakan SPSS dapat dilihat pada tabel di bawah ini.

TABEL 3

Regresi Linear Berganda

\begin{tabular}{|c|c|c|c|c|c|}
\hline \multirow[b]{2}{*}{ Model } & \multicolumn{2}{|c|}{$\begin{array}{l}\text { Unstandardized } \\
\text { Coefficients }\end{array}$} & \multirow{2}{*}{$\begin{array}{c}\begin{array}{c}\text { Standardized } \\
\text { Coefficients }\end{array} \\
\text { Beta }\end{array}$} & \multirow[b]{2}{*}{$\mathrm{t}$} & \multirow[b]{2}{*}{ Sig. } \\
\hline & $\mathrm{B}$ & Std. Error & & & \\
\hline $\begin{array}{ll}1 & \text { (Constant) }\end{array}$ & 8.701 & 4.767 & & 1.825 & .074 \\
\hline Pengembangan Karir & .356 & .166 & .335 & 2.139 & .038 \\
\hline Motivasi & .420 & .161 & .409 & 2.614 & .012 \\
\hline
\end{tabular}


Dari tabel 3 di atas, diperoleh bahwa nilai konstanta dari hasil penelitian diperoleh sebesar 8,701 dan koefisien regresi pengembangan karir sebesar 0,356 dan koefisien regresi motivasi sebesar 0,420 sehingga persamaan regresi antara variabel $X$ (pengembangan karir dan motivasi) terhadap variabel $Y$ (kepuasan kerja) adalah :

$$
\dot{Y}=8,701+0,356 X_{1}+0,420 X_{2}
$$

Dari persamaan regresi tersebut didapatkan nilai konstanta sebesar
8,701, sedangkan nilai koefisien pengembangan karir 0,356 dan nilai koefisien motivasi sebesar 0,420. Artinya jika variabel pengembangan karir dan motivasi 0 maka kepuasan kerja sebesar 8,701.

\section{Koefesien Korelasi}

Selanjutnya, diperoleh model sumari Uji $R$ untuk mengetahui besarnya koefesien korelasi antara $X$ dan $Y$ yang dapat dilihat pada tabel di bawah ini.

TABEL 4

Model Sumari Uji R Untuk Mengetahui Besarnya Hubungan Antara X dan $Y$

\begin{tabular}{|l|c|r|r|c|}
\hline Model & R & R Square & $\begin{array}{c}\text { Adjusted R } \\
\text { Square }\end{array}$ & $\begin{array}{c}\text { Std. Error of the } \\
\text { Estimate }\end{array}$ \\
\hline 1 & $.696^{\mathrm{a}}$ & .484 & .463 & 1.23745 \\
\hline
\end{tabular}

Selanjutnya menginterpretasi koefisien korelasi sesuai dengan tabel berikut ini.

\section{TABEL 5}

Koefesien Korelasi

\begin{tabular}{|c|c|}
\hline Interval koefisien & Tingkat Hubungan \\
\hline $0,00-0,199$ & Sangat Rendah \\
\hline $0,20-0,399$ & Rendah \\
\hline $0,40-0,599$ & Sedang \\
\hline $\mathbf{0 , 6 0 - 0 , 7 9 9}$ & Kuat \\
\hline $0,80-1,000$ & Sangat kuat \\
\hline
\end{tabular}

Sumber: (Sugiyono, 2016)

Berdasarkan tabel 4 koefesien korelasi sebesar 0,696 dan berdasarkan tabel 5 angka ini kategori kuat. Dengan demikian dapat disimpulkan bahwa tingkat hubungan pengembangan karir dan motivasi dengan kepuasan kerja dikategorikan kuat.

\section{Koefisien Determinasi}

Berdasarkan perhitungan koefisien determinasi tersebut didapatkan sebesar 48,4\%. Maka dapat disimpulkan bahwa pengembangan karir dan motivasi berpengaruh terhadap kepuasan kerjasebesar $48,4 \%$, sedangkan $51,6 \%$ dipengaruhi oleh faktor lain yang tidak disebutkan dalam penelitian ini seperti minat, disiplin kerja, sarana dan prasarana, pendidikan, dan sebagainya.

\section{Uji Hipotesis}

Uji hipotesis dalam penelitian ini terdiri dari uji parsial (uji $t$ ) dan uji secara simultan $(F)$.

\section{Uji Secara Parsial}

Uji Secara Parsial dalam penelitian ini menggunakan uji $t$ dengan menggunakan program SPSS versi 22.00 for windows. Adapun hasil pengujian hipotesis secara parsial dapat dilihat pada tabel di bawah ini. 
TABEL 6

Hasil Uji T Secara Parsial

Coefficients $^{a}$

\begin{tabular}{|c|c|c|c|c|c|}
\hline \multirow[b]{2}{*}{ Model } & \multicolumn{2}{|c|}{$\begin{array}{c}\text { Unstandardized } \\
\text { Coefficients }\end{array}$} & \multirow{2}{*}{$\begin{array}{c}\begin{array}{c}\text { Standardized } \\
\text { Coefficients }\end{array} \\
\text { Beta }\end{array}$} & \multirow[b]{2}{*}{$\mathrm{t}$} & \multirow[b]{2}{*}{ Sig. } \\
\hline & $\mathrm{B}$ & Std. Error & & & \\
\hline $\begin{array}{ll}\mathbf{1} & \text { (Constant) }\end{array}$ & 8.701 & 4.767 & & 1.825 & .074 \\
\hline Pengembangan Karir & .356 & .166 & .335 & 2.139 & .038 \\
\hline Motivasi & .420 & .161 & .409 & 2.614 & .012 \\
\hline
\end{tabular}

a. Dependent Variable: Kepuasan Kerja

Berdasarkan tabel 6 di atas, diketahui bahwa hasil signifikan variabel pengembangan karir terhadap kepuasan kerja sebesar 0,038<0,05 (5\%). Selain itu, nilai uji thitungsebesar 2,139, sedangkan nilai tabel sebesar1,67655, sehingga nilai thitung= $2,139>t_{\text {tabel }}=1,67655$. Dengan demikian Ho ditolak dan Ha diterima, sehingga dapat disimpulkan bahwa terdapat pengaruh yang signifikan antara variabel pengembangan karir terhadap kepuasan kerja pegawai pada Kantor Badan Pendapatan Daerah Provinsi Sumatera Selatan.

Selain itu, hasil signifikan variabel motivasi terhadap kepuasan kerja sebesar 0,012<0,05 (5\%). Selain itu, nilai uji thitungsebesar 2,614, sedangkan nilai tabel sebesar 1,67655, sehingga nilai $t_{\text {hitung }}=2,614>t_{\text {tabel }}=$ 1,67655. Dengan demikian Ho ditolak dan $\mathrm{Ha}$ diterima, sehingga dapat disimpulkan bahwa terdapat pengaruh yang signifikan antara variabel motivasi terhadap kepuasan kerja pegawai pada Kantor Badan Pendapatan Daerah Provinsi Sumatera Selatan.

\section{Uji Secara Simultan}

Uji secara simultan dalam penelitian ini menggunakan uji $F$ dengan menggunakan program SPSS versi 22.00 for windows.Adapun hasil pengujian hipotesis secara parsial dapat dilihat pada tabel di bawah ini.

TABEL 7

HASIL UJI T SECARA SIMULTAN

ANOVA $^{\mathrm{a}}$

\begin{tabular}{|ll|r|r|r|r|r|}
\hline Model & Sum of Squares & Df & Mean Square & F & Sig. \\
\hline 1 & Regression & 69.008 & 2 & 34.504 & 22.533 & $.000^{\mathrm{b}}$ \\
& Residual & 73.502 & 48 & 1.531 & & \\
Total & 142.510 & 50 & & & \\
\hline
\end{tabular}

a. Dependent Variable: Kepuasan Kerja

b. Predictors: (Constant), Motivasi, Pengembangan Karir

Berdasarkan tabel 7 di atas, diketahui bahwa hasil signifikan variabel pengembangan karir dan motivasi terhadap kepuasan kerja sebesar $0,000<0,05(5 \%)$. Selain itu, nilai uji $F_{\text {hitung }}$ sebesar 22,533, sehingga nilai $F_{\text {hitung }}=22,533>F_{\text {tabel }}=$ 1,60. Dengan demikian dapat disimpulkan bahwa Ho ditolak dan $\mathrm{Ha}$ diterima, sehingga dapat disimpulkan bahwa terdapat pengaruh yang signifikan antara variabel pengembangan karir dan motivasi secara bersama-sama terhadap kepuasan kerja pegawai pada Kantor 
Badan Pendapatan Daerah Provinsi Sumatera Selatan.

\section{2) Pembahasan}

Tujuan penelitian ini adalah untuk mengetahui pengaruh pengembangan karir dan motivasi terhadap kepuasan kerja pegawai pada Kantor Badan Pendapatan Daerah Provinsi Sumatera Selatan.

Berdasarkan hasil penelitian diperoleh bahwa nilai konstanta sebesar 8,701 koefisien regresi pengembangan $\operatorname{karir}\left(X_{1}\right)$ sebesar 0,356 dan koefisien regresi motivasi $\left(X_{2}\right)$ sebesar 0,420 . Dengan demikian, jika koefisien bernilai 0 , maka variabel kepuasan kerja sebesar 8,701. Dengan demikian, jika pengembangan $\operatorname{karir}\left(X_{1}\right)$ naik 1 satuan dan motivasi $\left(X_{2}\right)$ dianggap konstan maka kepuasan kerja $(Y)$ meningkat sebesar 0,356 satuan. Demikian juga, jika terjadi penurunan pengembangan karir $\left(X_{1}\right) 1$ satuan dan motivasi $\left(X_{2}\right)$ dianggap konstan maka kepuasan $\operatorname{kerja}(Y)$ menurun sebesar 0,356 .

Jika motivasi $\left(X_{2}\right)$ naik 1 satuan dan pengembangan karir $\left(X_{1}\right)$ dianggap konstan maka kepuasan kerja (Y) meningkat sebesar 0,420 satuan. Demikian juga, jika terjadi penurunan motivasi $\left(X_{2}\right) 1$ satuan dan pengembangan karir $\left(X_{1}\right)$ dianggap konstan maka kepuasan kerja (Y) menurun sebesar 0,420.

Berdasarkan

perhitungan koefisien korelasi didapatkan nilai $\mathrm{r}_{\text {hitung }}$ sebesar 0,696 , sedangkan $r_{\text {tabel }}(0,05 ; 51)=$ 0,271 . Sehingga nilai $r_{\text {hitung }}=0,696>$ $r_{\text {tabee }(0,05 ; 51)}=0,271$. Dengan demikian pengembangan karir dan motivasi berpengaruh signifikan terhadap kepuasan kerja. Hasil perhitungan menunjukkan bahwa nilai koefisien korelasi sebesar 0,696 yang termasuk dalam kategori kuat.
Berdasarkan

perhitungan koefisien determinasi diperoleh sebesar 48,4\% maka dapat disimpulkan bahwa pengembangan karir dan motivasi berpengaruh terhadap kepuasan kerja sebesar $48,4 \%$, sedangkan $51,6 \%$ dipengaruhi oleh faktor lain yang tidak dimasukkan dalam penelitian ini seperti motivasi, minat, disiplin kerja, sarana dan prasarana, pendidikan dan sebagainnya.

\section{Pengaruh Pengembangan Karir terhadap Kepuasan Kerja Pegawai pada Kantor Badan Pendapatan Daerah Provinsi Sumatera Selatan}

Berdasarkan hasil perhitungan diperoleh nilai signifikan variabel pengembangan karir terhadap kepuasan kerja sebesar 0,038 < $0,05(5 \%)$. Selain itu uji thitungsebesar 2,139 , sedangkan nilai $t_{\text {tabel }}$ sebesar 1,67655 , sehingga nilai $t_{\text {hitung }}=2,139$ $>t_{\text {tabel }}=1,67655$. Dengan demikian dapat disimpulkan bahwa terdapat pengaruh yang signifikan antara variabel pengembangan karir terhadap kepuasan kerja pegawai pada Kantor Badan Pendapatan Daerah Provinsi Sumatera Selatan.

Hasil penelitian ini sejalan dengan yang dilakukan oleh Wijayanti (2017) yang meneliti mengenai Pengaruh Pengembangan Karir dan Motivasi terhadap Kepuasan Kerja Karyawan pada PT Inka (Persero) Madiun. Hasil penelitian ini menemukan bahwa pengembangan karir berpengaruh positif terhadap kepuasan kerja. Hal tersebut terbukti dengan nilai t hitung sebesar 6,944 dengan probabilitas 0,000 dimana angka tersebut signifikan karena $(p<0,05)$. 
Pengaruh Motivasi terhadap Kepuasan Kerja Pegawai pada Kantor Badan Pendapatan Daerah Provinsi Sumatera Selatan

Selain itu, hasil signifikan variabel motivasi terhadap kepuasan kerja sebesar 0,012<0,05 (5\%). Selain itu, nilai uji thitungsebesar 2,614, sedangkan nilai $t_{\text {tabel }}$ sebesar 1,67655 , sehingga nilai thitung $=2,614>$ trabel $=1,67655$. Dengan demikian Ho ditolak dan $\mathrm{Ha}$ diterima, sehingga dapat disimpulkan terdapat pengaruh yang signifikan antara variabel motivasi terhadap kepuasan kerja pegawai pada Kantor Badan Pendapatan Daerah Provinsi Sumatera Selatan.

Hasil ini sejalan dengan penelitian yang dilakukan oleh Wijayanti (2017) yang meneliti mengenai Pengaruh Pengembangan Karir dan Motivasi terhadap Kepuasan Kerja Karyawan pada PT Inka (Persero) Madiun. Hasil penelitian menemukan bahwa motivasi berpengaruh positif terhadap kepuasan kerja. Hal tersebut terbukti dengan nilai $t$ hitung sebesar 11,185 dengan probabilitas 0,000 dimana angka tersebut signifikan karena $(p<0,05)$.

\section{Pengaruh Pengembangan Karir dan Motivasi terhadap Kepuasan Kerja Pegawai Pada Kantor Badan Pendapatan Daerah Provinsi Sumatera Selatan}

Berdasarkan hasil pengujian hipotesis secara bersama-sama diperoleh bahwa hasil signifikan variabel pengembangan karir dan motivasi terhadap kepuasan kerja sebesar $0,000<0,05(5 \%)$. Selain itu,

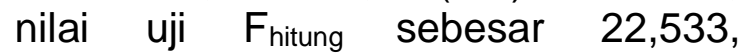
sedangkan nilai $F_{\text {tabel }}$ diperoleh $F_{\text {tabel }}$ sebesar 1,60 , sehingga nilai $F_{\text {hitung }}=$ $22,533>F_{\text {tabel }}=1,60$. Dengan demikian Ho ditolak dan Ha diterima, sehingga dapat disimpulkan bahwa terdapat pengaruh yang signifikan antara variabel pengembangan karir dan motivasi secara bersama-sama terhadap kepuasan kerja pegawai pada Kantor Badan Pendapatan Daerah Provinsi Sumatera Selatan.

Hasil penelitian ini sejalan dengan penelitian yang dilakukan Wijayanti (2017) yang meneliti mengenai pengaruh Pengembangan Karir dan Motivasi terhadap Kepuasan Kerja Karyawan pada PT Inka (Persero) Madiun. Hasil penelitian menemukan bahwa Pengembangan Karir dan Motivasi berpengaruh secara simultan atau bersama-sama terhadap Kepuasan Kerja. Hal tersebut terbukti dengan nilai Fhitung sebesar 206,619 dengan probabilitas 0,000 dimana angka tersebut signifikan karena $(p<0,05)$.

\section{G. KESIMPULAN DAN SARAN}

1. Kesimpulan

Berdasarkan hasil penelitian dan pembahasan pada bab sebelumnya dapat disimpulkan sebagai berikut.

a)

b) Ada pengaruh yang signifikan antara pengembangan karir terhadap kepuasan kerja pegawai pada Kantor Badan Pendapatan Daerah Provinsi Sumatera Selatan yang dilihat dari thitung $=$ $2,139>t_{\text {tabel }}=1,67655$.

c) Ada pengaruh yang signifikan antara motivasi terhadap kepuasan kerja pegawai pada Kantor Badan Pendapatan Daerah Provinsi Sumatera Selatan yang dilihat dari thitung $=$ $2,614>$ tabel $=1,67655$.

d) Ada pengaruh yang signifikan antara pengembangan karir dan terhadap kepuasan kerja pegawai pada Kantor Badan Pendapatan Daerah Provinsi Sumatera Selatan yang dilihat dari $\mathrm{F}_{\text {hitung }}=$ 
22,533> $F_{\text {tabel }}=1,60$. Berdasarkan perhitungan koefisien korelasi tersebut didapatkan nilai sebesar $\mathrm{r}_{\text {hitung }}=0,696$ yang termasuk dalam kategori kuat, sedangkan hasil perhitungan koefisien determinasi diperoleh sebesar $48,4 \%$. Disimpulkan bahwa pengembangan karir dan motivasi berpengaruh terhadap kepuasan kerjasebesar 48,4\%, sedangkan $51,6 \%$ dipengaruhi oleh faktor lain yang tidak disebutkan dalam penelitian ini.

2. Saran

Sehubungan dengan simpulan di atas, maka peneliti memberikan saran sebagai berikut.

1. Pengembangan karir mempunyai pengaruh positif terhadap kepuasan kerja pegawai. Berdasarkan hal tersebut, maka penting bagi Kantor Badan Pendapatan Daerah Provinsi Sumatera Selatan untuk mampu mengembangkan karir atau potensi mereka berupa promosi jabatan serta pendidikan dan pelatihan kerja agar pegawai semakin baik dalam bekerja dan puas atas hasil yang ia kerjakan.

2. Motivasi mempunyai pengaruh yang positif terhadap kepuasan kerja pegawai. Berdasarkan hal tersebut, maka penting bagi Kantor Badan Pendapatan Daerah Provinsi Sumatera Selatan untuk mampu meningkatkan semangat kerja pegawai dengan memberikan hadiah atau penghargaan kepada pegawai yang berprestasi baik. Dengan memberi motivasi, semangat kerja pegawai akan meningkat sehingga pekerjaan yang ia kerjakan mendapatkan hasil yang memuaskan.

3. Secara simultan (bersamasama) pengembangan karir dan motivasi mempunyai pengaruh yang positif terhadap kepuasan kerja pegawai. Berdasarkan hal tersebut, maka penting bagi Kantor Badan Pendapatan Daerah Provinsi Sumatera Selatan untuk mampu mengembangkan karir mereka dengan memberikan pelatihan dan memberikan motivasi atau dorongan kepada mereka berupa pemberian penghargaan bagi yang berprestasi baik, agar terciptannya kepuasan kerja pegawai pada Kantor Badan Pendapatan Daerah Provinsi Sumatera Selatan secara efektif dan efisien.

\section{DAFTAR PUSTAKA}

Fahmi, Irham. 2017. Manajemen Sumber Daya Manusia. Teori dan Aplikasi. CV. Alvabeta, Bandung.

Hamali, Arif.Y. 2018. Pemahaman Manajemen Sumber Daya Manusia. Yogyakarta : CAPS (Center For Academik Publishing Service)

Lisdiani, Vendriana. 2017. Pengaruh Pengembangan Karir Terhadap Kepuasan Kerja Karyawan Melalui Motivasi Kerja Sebagai Variabel Intervening (Studi Kasus Pada Hotel Grasia Semarang). Diponegoro : Administrasi Bisnis, Universitas Diponegoro Journal Of Social and Political Science, 2017 hal 1-8

Noor, Juliansyah. 2013. Penelitian IImu Manajemen. Tinjauan Filosofis dan Praktis. Jakarta: Kencana Prenada Media Group 
Priyatno. $D$ 2014. Pengelola Data Terpraktis SPSS 22. Yogyakarta : Andi

Rivai, Veithzal. 2014. Manajemen Sumber Daya Manusia Untuk Perusahaan. Cetakan ke-4. PT. Raja Grafindo Persada : Jakarta

Sugiyono. 2013. Metode Penelitian Kuantitatif, Kualitatif, dan Kombinasi (Mixed Methods). Bandung: Alfabeta 2016. Metode Penelitian Kuantitatif, Kualitatif, dan R\&D. Bandung: Alfabeta 2016. Metode Penelitian Manajemen. Bandung: Alfabeta 2017. Metode Penelitian Kuantitatif, Kualitatif, dan R\&D. Bandung: Alfabeta 2018. Metode Penelitian Kuantitatif, Kualitatif, dan $R \& D$. Bandung: Alfabeta

Samsudin, Sadili. 2010. Manajemen Sumber Daya Manusia. Bandung : CV. Pustaka Setia

Sinambela. 2016. Manajemen Sumber Daya Manusia. Jakarta : PT. Bumi Aksara

Siregar, Syopian. 2013. Metode Penelitian Kuantitatif. Jakarta : PT. Fajar Interpratama Mandiri

Sutrisno, Edy. 2015. Manajemen Sumber Daya Manusia. Jakarta : Kencana Prenada Media Group

Sujarweni, V.W. 2015. Metodologi Penelitian Bisnis \& Ekonomi. Yogyakarta : PT. Pustaka Baru

Wibowo. 2014. Manajemen Kinerja. Jakarta: PT. Raja Grafindo Persada
Wijayanti, Ika. $R$, dkk. 2017. Pengaruh Pengembangan Karir dan Motivasi Terhadap Kepuasan Kerja Karyawan PT. Inka. (Persero). Madiun : Pendidikan Akuntansi FKIP Universitas PGRI Madiun, Oktober 2017, Vol. 5 No. 1 ISSN : 2337-9723 